\title{
THE BALANCE CONCEPTS OF EDUCATION BASED ON ISLAM PERSPECTIVE
}

\author{
Abdul Wahab Syakhrani ${ }^{1}$ \\ ${ }^{1}$ STAI Rasyidiyah Khalidiyah Amuntai Kalimantan Selatan, Indonesia \\ Contributor Email: aws.kandangan@gmail.com
}

\begin{abstract}
This Islamic literature study tried to arrange the concept of education in Islam. To successfully compile, a series of reading reviews have been carried out starting from the formulation of the problem and continued with the collection of data from various sources related to the topic of discussion. After the collection of reading material and continued with the process of analysis in depth so that the reading material receives high understanding and interpretation. Finally, the preparation is done carefully and ensures the results of the study or findings in answering the problem of meeting the principles of validity and reliability as suggested by each scientific study. Finally the findings can be compiled, among others, that the principles and concepts of education in Islam is holding to the concept of a balance between world life and the hereafter. That is, among others, the difference between Islamic education and non-Islamic education with guidelines on the Koran and alhadis. Therefore, this Islamic study has contributed to the development of teaching and community what is a balance life in this world through researching the basic concept of life education based on Islamic perspective.
\end{abstract}

Keywords: Islamic Concept, Islam Education, Literature Study and Balance Life

\section{A. Introduction}

Since God created man, God has taught the Prophet Adam and Eve about the nature and meaning of education which includes prohibitions and commands to be obeyed. (Sutoyo, 2014). The concepts and initial models of education taught include truth, goodness and beauty, where truth, goodness and beauty must all be united in one's personal being. The concept of education taught by Allah includes verses 
of kauniyah and verses of qauliyah to reach the truth, goodness, and beauty. Likewise he must understand which areas of absolute truth are God and which areas of relative truth are human interpretations. (Buseri, 2014).

Likewise with the principle of balance which is no less important in Islamic education, this principle is the difference between Islamic education and non-Islamic education, because in the Koran God commands us that between world life and the hereafter must be balanced. The world can be a way for humans to do the good they planted and then reap the rewards in the hereafter. The concept of education in Islam is sourced from the Qur'an and Hadith and is a guideline in human life closely related to the cognitive, effective and psychometric outcomes of students. (Zhoc et al., 2019). This research is a literature study, to see further about the meaning and nature of the concept of true Islamic education.

\section{B. Method}

To complement the study of the concept of education in Islam, this study uses a literature review, (Aslan, 2017; Aslan, 2019). Through literature studies, this Islamic study can be supported by data needed from analyzing efforts to answering the questions being investigated. Furthermore, through the selection of this literature review method, this research will obtain an overview of information and ideas in accordance with other topics and content from various related reading sources and have relevant research objectives and questions related to "the concept of Education in Islam". As suggested by Zed, (2008) that to facilitate the process of this research, the literature study phase starts from reviewing the topic of discussion and collecting data from existing research in accordance with the problem of this research.

After that, the reading analysis process is critical so that it is easy to evaluate. (Cottrell, 2017). Then the process of organizing data by adjusting to the topic of study. Finally, the process of writing and the last review is done so that the results of the study can meet the principles of validity and reliability. 


\section{Finding and Discussion}

The concept of education in Islam is a series of education that teaches something good so that it finds several research results including;

\section{The Nature of Truth in Islamic Education}

The essence of "truth" has been formulated with several terms, such as aletheia (Greek), veritas (Latin), and truth (English). Etymologically, aletheia means "escape attention, invisible and hidden". Then, it changes into a positive meaning, which is "something that is found, understood, seen, and sparkling". From this, it means "the power of light or evidence of reality", and "the discovery of reason for that evidence". The word veritas etymologically means "choice or belief in reason", or "something chosen or believed to reason". In this linguistic context truth means "what is understood and chosen reason", or "activities that cause reason to find and choose successfully.

Al-Ghazali often uses the term haqq-vanity (truth-error) in the ontology contest, the term sawab-khata '(precision-error) in the context of ijtihad and epistemological processes, the term valid-invalid (validinvalid) in the context of epistemological processes, and legal status ", and the term sidq-kizb (true-lie) in the context of oral statements.

According to Al-Ghazali, haqq is a vanity opponent. It is used for several senses; First, pointing to an objective (reality, the real exist). Second, pointing to the existence of subjective, mental concepts that are in accordance with the reality of the object; in this sense, it is a science; and Third, pointing to the words; in this sense he is sidq as opposed to kizb. Thus, in the sense of propositions and sense concepts about objects that are in accordance with the reality of the objects themselves, truth (haqq) is identical to science. This meaning is also used by Arab semantic experts, namely that haqq is a decision that is compatible with reality, both in terms of speech and in the sense of belief and religion. (Anwar, 2000).

According to Lickona (2015), the most important measure of a nation is not seen from its economic well-being, technological genius, or military, but the most important measure of a nation is seen from the character or morality of its people. At the level of Elementary Education 
(SD) or Madrasah ibtidaiyah (MI), there is a principle to develop skills or life skills. Learning life skills include children learning to help themselves, being independent, responsible, and having self-discipline. Therefore, among the good values to be instilled in children Elementary school age (SD) / Madrasah Ibtidaiyah (MI) is the value of discipline to develop moral development, so it is very important at an early age or at the basic level of a child that the value of discipline is included in him.(Putra, 2019)

For example, whatever is known can basically be grouped into two: (1) some are still or only in the form of ideas or concepts. For example, the concepts of "people", "stones", etc., and (2) some are in the form of sentences, statements, or expressions. For example, the phrase "there is no God but Allah", "every living thing, including me, will surely die", "salty sea water", and so on. The second type of knowledge is a combination of these basic concepts. This conceptual combination is called tasdiq, which is a statement that contains a truth value and is a truth claim. If the scholars of ushul fiqh call it "khabar", then in terms of modern logic, tasdiq is more or less the same as a proposition.

The question that arises then is: how, with what, or from which problems can be known and confirmed? Borrowing the formulation of modern philosophical discourse: how is knowledge possible? The answer is through three sources, namely sensory perception (idrak al-hawass), common sense processes (ta'aqqul), and heart intuition (qalb), and through correct information (khabar sadiq). As pointed out in the Koran, sura an-Nahl: 78, "And Allah brought you out of your mother's stomach in a state of knowing nothing, and He gave you hearing, vision and heart, so that you will be grateful." (Husaini and Kania, 2013).

Sensory perceptions include the five (listener, seer, taste, smell, touch), plus a sixth sense called al-hiss al musytarak or census communis which includes memory or memory (dhakirah), imagery (imagination) or imagination, and power estimation (wahm). The process of reason includes reason (nzar) and thought flow (fikr). With this reason and flow you can articulate, make propositions, express opinions, argue, make analogies, make decisions and draw conclusions. Furthermore, with the intuition of the heart one can catch magical messages, divine cues, receive 
inspiration, fath, kasyf, and so on. Another source that is not less important is the news that comes from and relies on authority. The source of khadi sadiq, especially in religious matters, is revelation (Kalam Allah and the Sunnah of His Messenger) which is received and passed on, namely transmitted (ruwiya) and transferred (nuqila) until the end of time.

Because what we know can be expressed in the form of statements or propositions, then based on the sources mentioned above, our knowledge can be classified as follows: first: knowledge in the form of propositions or statements that point to objects of sensory perception (alhissiyat). As our knowledge of honey tastes sweet. Second, in the form of expressions that refer to things that we know as "a priori" (al-badihiyyat or al-'aqliyyat), such as $1 / 2$ is greater than $1 / 4$. Third, statements that represent intuition (al-hadsiyyat), mystical experience, spiritual vision, or supernatural (al-kasyfiyyat). Such knowledge is given to prophets and pious people. Fourth, statements containing the news of revelation that was heard (as-sam'iyyat), narrated (al-inarwiyyat), or quoted (annaqliyyat), and authoritative sources. (Husaini and Kania, 2013).

The second important epistemological quality of al-Quran is its emphasis on truth (al-haq), and certainty (al-yaqin), as the antithesis of error (al-bathil), doubt (al-syak), and conjecture (al-zhann). These concepts come to the surface when the mecca people refuse to accept the teachings of God brought by the Prophet, namely the opposition between the knowledge that God gives directly to human knowledge.A similar usage between zhann and haq is seen in 53:28, where the people of Mecca refer to Muhammad's message as merely a hoax (asathir). "And they (the people of Mecca) do not know the slightest knowledge about it, they are nothing but following prejudices, whereas those prejudices are not the least bit useful for achieving truth (53:28)". Importantly, the truth that cannot be doubted is from God, whose absolute certainty (haqq al-yaqin, 69:51). There are three levels of certainty: cognitive certainty ('science alyaqin), certainty of vision (' ain al-yaqin), and absolute certainty experienced (haq al-yaqin). (Daud, 1997). 
According to Wan Mohd. Nor Wan Daud, zhan is not entirely a negative epistemological concept in Islam, because besides the great emphasis of the Qur'an on the truth and certainty of knowledge, humans can also know data other than the Qur'an. Zhann (conjecture) is the opposite of the word 'ilm, haq, and yaqin, especially, in the context of God's knowledge. But in two places, 2: 40-46 and 2: 249, zhann believers, based on the guidance of the knowledge of revelation, can reach the meaning of yaqin (definite knowledge). (Daud, 1997).

\section{The Nature of Goodness in Islamic Education}

The meaning of ethics is used in two forms of meaning, first, ethics is a collection of knowledge about the evaluation of human actions. Second, is a predicate used to distinguish things, deeds, or other humans. Formal objects of ethics include the norms of human decency, and study the behavior of human beings both good and bad. (Susanto, 2011). The notion of Islamic ethics is not much different from the notion of ethics in general, it's just that the understanding of Islamic ethics is more directed to the regulation of human life during his life in the world and preparation for the afterlife. (Rahmaniyah, 2020).

It is well known that ethics is a philosophical study of morals (Walker, 2007). So, the main problem is about "moral nature". Moral is a matter of behavior in relation to oneself and each other, the extent to which it contains the value of kindness. What is the measure so that a behavior is of good value? Is goodness relative or absolute? Is it good for someone to steal medicine to cure a family member who is seriously ill on the grounds of not having money? To what extent is giving alms to beggars considered good?

From the series of questions, it seems that there is a relativity of the value of goodness, depending on which side the assessment is made. For healing purposes, functional medicine is always good value. But stealing behavior, viewed from any side is still contrary to the value of goodness. Alms for people who are starving is a good deed. But from a different side, it could be precisely training beggars to be lazy. It is well known that laziness is a behavior that threatens the development of individual 
creativity potential. If individual creativity systemically does not grow, the development of people's lives becomes threatened. It all contradicts the nature of education, namely the development of a vision of life (the maturation of spiritual potential) and the development of life creativity (intellectual maturation), namely the development of life skills and skills. The nature of goodness which becomes a central issue of ethics is "good value" according to all aspects. Viewed from any side, the value of goodness never changes. So it is absolute. (Suharto, 2007).

Islam emphasizes that in the direction of virtue, must also use the usual intermediary tools, which are not contrary to Islamic law such as the act of respect that is done by the child to parents must still be placed in a reasonable position, which is respected and treated well. But on the other hand, all his orders that deviate from Islamic teachings, must not be obeyed. Therefore, Islam teaches that a Muslim who does good works must be due to Allah. (Sofyan, 2010).

\section{Essence of beauty in Islamic education}

Aesthetics is a branch of philosophy that questions art and beauty. The term aesthetic comes from the Greek aisthesis, which means sensory absorption, intellectual understanding, can also mean spiritual observation. The term aisthesis also comes from Latin more closely the word art, which means art, skill, skill, and science. (Abdullah, 2006).

Regarding esthetics, Setiawan explained as "the study of the nature of beauty in the fine art", learning about the nature of beauty in art. Aesthetics is a branch of philosophy which studies the nature of beauty and evil. Aesthetics help guide in forming a good perception of scientific knowledge so that it can be easily understood by a wide audience. Aesthetics are also related to the quality and formation of aesthetic modes of scientific knowledge. (Susanto, 2011).

Anyone who has ever talked a little about truth and goodness, will quickly remember the third term in the well-known Trinity that is beauty. Epistemology is related to the theory of truth, ethics is related to the theory of good in terms of decency. The term 'axiology' is used to limit the understanding of inquiry about the general good. As for the investigation 
of the nature of beauty called 'aesthetics'. Nevertheless, aesthetics also questions theories about art. (Katsoff, 1992).

Paying attention to what is presented by al-Attas, that both nature and the Koran are both revelations, this shows that God is the only source of truth, even at the same time the only source of goodness and beauty.

Verses of qauliyah and verses of kauniyah which both belong to Allah become a source of knowledge for mankind, on the one hand and at the same time a source of teachings about goodness and beauty on the other side. In the mention of the Koran itself these three things are known by the term hanief which is straight which also means true, good and beautiful. Allah confirms in Q.S. Ruum verse 30. As for what is meant by the nature of God, which is the origin of God's creation in humans, which has a tendency to something straight or has a tendency to truth, goodness and beauty. These three components must be integrated in a person because it is not appropriate if someone only loves the truth but does not love the good, or does not love beauty. (Buseri, 2014).

\section{The principle of balance in Islamic education}

Islamic education in its goals is not only upright on the principle of balance and simplicity, which among others means to realize the desired balance between various aspects of growth in one's person and life and also in people's lives. Likewise it means creating a balance in satisfying the various needs of individuals and groups, and is a balance between the demands of preserving past cultures and present needs and trying to overcome their problems, and the demands of future needs, without exaggerating one aspect of another aspect. (al-Syaibany, 1979).

This principle is very important in the development of Islamic education and is the basic teachings that distinguish Islamic education from non-Islamic education. Islamic education maintains the continuity between the interests of world life and the afterlife, based on the guidance of the Koran surah al-Qashash verse 77.

This principle according to Muhammad Munir Mursi establishes that Islamic education is not shufiyah education or rahbaniah education, and vice versa not also materialism education or positivism. So, it is not 
solely for the benefit of developing worldly aspects or vice versa, not for the afterlife aspects.. (as-Sa'id, 2011). Thus, Islamic education based on this principle is education that is content to be filled, complete, complete, and necessary-requires one another in its goals and focuses, in which all aspects of development that are promoted are complete-completing and everything goes in stages similar or almost similar. (al-Syaibany, 1979). It is this moderate principle or balance that makes Islamic education, which has an essential identity, between two extreme ideologies. In addition, Islamic education is education that preserves the values of human equilibrium that are natural. Fitrah itself is the origin of human events in the order of God's creation. (as-Sa'id, 2011).

Science in Islam is based on intellect, which directs the ratio to form science that is based on awareness and faith in the power of Allah. (Günther, 2006). This is the knowledge that guides (guidance) from darkness to light (nur). A science that carries the mission of the welfare of human life, the world and the hereafter. In this science, intellect is played as a medium to make breakthroughs of thought, the sharpening of ideas, reflections on natural phenomena, both exact and social phenomena, and excavations of scientific treasures. While the faith is positioned as a provider of guidance and direction towards the direction to be wandered by the wandering of the intellect. No matter how the intellect is given the opportunity to make the maximum wandering of reasoning, but within the limits that can be controlled by the faith in the power of God, so as to produce knowledge that gives awareness to humans to know their true identity, which is a self identity that remains as a servant of God given the trust to be creative. (Qomar, 2012).

Science in Islam in presenting an offer of intellectual development, but still pay attention to human values. (Cromer, 1995). This means that he puts humans in their true position, and gives trust to humans within the limits of their capacity, so they do not overstep the role of God. On the basis of this perception, we must always appear to the level of correct knowledge about Islam and the Islamic worldview, so that the knowledge of any of the sciences we can seek will always be in a reasonable balance 
with the knowledge of Islam and the true Islamic worldview, to maintain rules of knowledge in us. That balance involves intellectual wandering with submission to God, needs that are sacred to the profane, respect for human beings with exaltation of God, reasoning with revelation, attention to empirical and metaempiris issues, thinking with remembrance, efforts with charity, and so on. Seginer, (2019) suggested that human future life and orientation based beliave and life perspectives. Balance serves to bridge the interests of the vertical relationship (oriented toward selfapproach to God) with the horizontal relationship (fellow human beings in the fabric of social relations.

\section{Conclusion}

Between truth, goodness and beauty all three must be united in a Muslim because it is not right if someone only loves the truth but denies goodness or even does not love beauty because God is beautiful and loves beauty. The principle of balance in Islamic education is the difference between Islamic education and non-Islamic education because Islamic education maintains the continuity between the interests of the world and the interests of the hereafter as the word of God in the Koran surah al-Qashash verse 77. So, in Islamic education there must be values truth, goodness, and beauty and must have the principle of balance that originates from the Koran or al-Hadith as the main foundation so that it becomes a pattern of life and someone is able to distinguish between good and bad things according to His guidance.

\section{Bibliography}

Abdullah, M.Y., 2006. Pengantar studi etika. PT RajaGrafindo Persada, Jakarta.

al-Syaibany, O.M. al-Toumy, 1979. Falsafah Pendidikan Islam, terj. Hasan Langgulung. Bulan Bintang, Jakarta. 
Anwar, S., 2000. Filsafat ilmu al-Galzali: (analisis tentang dimensi ontologi, epistemologi dan aksiologi ilmu era peripatetik). CV PUSTAKA SETIA, Bandung.

Aslan, 2019. Peran Pola Asuh Orangtua di Era Digital. Jurnal Studia Insania 7, 20-34. http://dx.doi.org/10.18592/jsi.v7i1.2269

Aslan, 2017. Pumping Teacher dalam Tantangan Pendidikan Abad 21. Muallimuna 2, 89-100.

as-Sa'id, M., 2011. Filsafat Pendidikan Islam. Mitra Pustaka, Yogyakarta.

Buseri, K., 2014. Dasar, Asas dan Prinsip Pendidikan Islam. IAIN Antasari, Banjarmasin.

Cottrell, S., 2017. Critical Thinking Skills: Effective Analysis, Argument and Reflection. Macmillan International Higher Education.

Cromer, A., 1995. Uncommon Sense: The Heretical Nature of Science. Oxford University Press USA, New York.

Daud, W.M.N.W., 1997. Konsep pengetahuan dalam Islam. Penerbit Pustaka, Bandung.

Günther, S., 2006. Be Masters in That You Teach and Continue to Learn: Medieval Muslim Thinkers on Educational Theory. Comparative Education Review 50, 367-388. https://doi.org/10.1086/503881

Husaini, A., Kania, D.D., 2013. Filsafat ilmu perspektif barat dan Islam. GEMA INSANI PRESS, Jakarta.

Katsoff, L.O., 1992. Pengantar Filsafat., Terj. Suyono Sumargono. Tiara Wacana, Yogyakarta.

Putra, P., 2019. Implementasi Sikap Disiplin Di Lembaga Madrasah Ibtidaiyah (Mi) Dalam Pembentukan Moral Anak 11, 10.

Qomar, M., 2012. Fajar Baru Islam Indonesia. Mizan, Bandung.

Rahmaniyah, I., 2020. Pendidikan Etika. UIN Malang Press, Malang. 
Seginer, R., 2019. Adolescent Future Orientation: Does Culture Matter? Online Readings in Psychology and Culture 6. https://doi.org/10.9707/2307-0919.1056

Sofyan, A., 2010. Kapita Selekta Filsafat. Pustaka Setia, Bandung.

Suharto, 2007. Pengembangan Materi dan Kegiatan Pembelajarannya dalam Kurikulum Tingkat Satuan Pendidikan Bidang Seni Musik. Harmonia: Of Arts Research And Education 8, 90-97.

Susanto, A., 2011. Filsafat Ilmu: Suatu Kajian dalam Dimensi Ontologis, Epistemologis, dan Aksiologis. PT Bumi Aksara, Jakarta.

Sutoyo, A., 2014. Human Dimension In The Perspective Of The Holy Quran. International Journal of Education 7, 71-83. https://doi.org/10.17509/ije.v7i2.5307

Zed, M., 2008. Metode Penelitian Kepustakaan. Yayasan Obor Indonesia, Jakarta.

Zhoc, K.C.H., Webster, B.J., King, R.B., Li, J.C.H., Chung, T.S.H., 2019. Higher Education Student Engagement Scale (HESES): Development and Psychometric Evidence. Res High Educ 60, 219244. https://doi.org/10.1007/s11162-018-9510-6 